\title{
A VaR-Based Methodology for Assessing Carbon Price Risk across European Union Economic Sectors
}

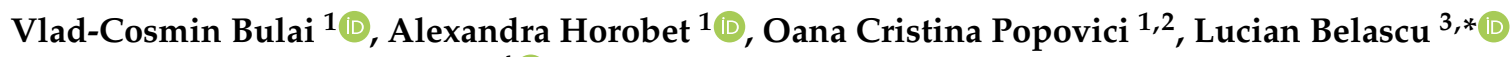 \\ and Sofia Adriana Dumitrescu ${ }^{4} \mathbb{B}$ \\ 1 Department of International Business and Economics, Bucharest University of Economic Studies, \\ 010374 Bucharest, Romania; vlad.bulai@rei.ase.ro (V.-C.B.); alexandra.horobet@rei.ase.ro (A.H.); \\ oana.popovici@rei.ase.ro (O.C.P.) \\ 2 Romanian Academy, Institute for Economic Forecasting, Bucharest University of Economic Studies, \\ 010374 Bucharest, Romania \\ 3 Department of Management, Marketing and Business Administration, "Lucian Blaga" University of Sibiu, \\ 550024 Sibiu, Romania \\ 4 Department of Accounting and Audit, Bucharest University of Economic Studies, \\ 010374 Bucharest, Romania; sofia.dumitrescu@cig.ase.ro \\ * Correspondence: lucian.belascu@ulbsibiu.ro
}

Citation: Bulai, V.-C.; Horobet, A.;

Popovici, O.C.; Belascu, L.;

Dumitrescu, S.A. A VaR-Based

Methodology for Assessing Carbon Price Risk across European Union Economic Sectors. Energies 2021, 14, 8424. https://doi.org/10.3390/ en14248424

Academic Editor: Behnam Zakeri

Received: 30 October 2021

Accepted: 10 December 2021

Published: 14 December 2021

Publisher's Note: MDPI stays neutral with regard to jurisdictional claims in published maps and institutional affiliations.

Copyright: (c) 2021 by the authors. Licensee MDPI, Basel, Switzerland. This article is an open access article distributed under the terms and conditions of the Creative Commons Attribution (CC BY) license (https:// creativecommons.org/licenses/by/ $4.0 /)$.

\begin{abstract}
The latest European Union measures for combating climate adopted in the "Fit for 55 package" envisage the extension of the Emissions Trading System, the first "cap-and-trade" system in the world created for achieving climate targets, which limits the amount of greenhouse gas emissions by imposing a price on carbon. In this context, our study provides an integrated assessment of carbon price risk exposure of all economic sectors in the European Union Member States, thus supporting decision making in determining the energy transition risk. We propose a novel approach in assessing carbon risk exposure using the Value at Risk methodology to compute the carbon price under the EU ETS, based on historical price simulation for January-August 2021 and ARMA-GARCH models for the October 2012-August 2021 period. We further built a value erosion metric, which allowed us to establish each sector's exposure to risk and to identify differences between Eastern and Western EU countries. We find that the refining sector appears to be highly vulnerable, whereas there is higher potential for large losses in the energy supply and chemical sectors in Eastern EU Member States, given a different pace of industry restructuring.
\end{abstract}

Keywords: carbon price risk; greenhouse gas emission; European Trade System; Value at Risk; ARMA-GARCH; European Union

\section{Introduction}

The most recent IPCC Report [1] signals unprecedented negative consequences of climate change, stating that greenhouse gas (GHG) emissions have contributed to an increase in the temperature by up to two degrees Celsius in the past several hundreds of years, which has been a unique surge in the last two millennia. Moreover, the global surface temperature will continue to rise until at least the mid-century, unless GHG emissions are drastically reduced. The recognition of the negative impact of pollution is an international level consensus. The United Nations Glasgow Climate Change Conference (UNFCCC COP26) taking place in November 2021 intended to achieve promises from world leaders that their countries will participate in a firm commitment to net-zero global carbon emissions by 2050. The COP26 Conference is a follow-up to the COP21 Conference in Paris in 2015, which resulted in the legally binding global climate change treaty that went into effect in November 2016.

The European Union (EU) initiatives were considered the most ambitious in reducing pollution at the global level. The EU is at the forefront of the fight against climate change 
and has become the first major economic area to develop and implement a legally binding framework aimed at attaining the Paris Agreement's objectives. Through the European Green Deal, launched at the end of 2019, the European Commission promoted a set of policy initiatives aimed directly at leading Europe to climate neutrality (or net-zero carbon emissions) by 2050 [2,3]. This was accompanied by an impact assessment plan towards reductions in the EU's GHG emissions of between 50 and 55\% in 2030 compared to 1990 levels. Despite the COVID-19 pandemic, the EU's efforts in the matter have not diminished. Moreover, the decline in the GHG emissions in the developed world fueled by lockdowns and slowdowns in economic activity during the first months of the pandemic has only ignited more sustained action towards carbon neutrality. As such, the EU advanced a thorough revision of its legislation in the areas of energy, climate, and transport, included in the so-called "Fit for 55 package", which is targeted at achieving its climate-related objectives for 2030 and 2050. Moreover, the EU was the first region to create a system of carbon markets that reconfigured incentives for businesses and diminished the amount of GHG emissions by imposing a price on carbon [4,5]. The EU Emissions Trading System (ETS) caps the total allowable GHG emissions and issues emissions allowances (EUA) that can be used for covering the emissions over a certain period. Such an approach imposes a framework on companies for achieving yearly reductions in pollution, given the annual decrease in the cap. Since the ETS Directive [6] was adopted in 2003, the system has been continuously developed in order to follow the EU's ambitious targets in fighting against climate change. The "Fit for 55 package", recently launched in the EU, also targets the extension of the EU ETS system in three main directions: the system will cover shipping, the rules for emissions from aviation will be revised, and a separate emissions trading system for road transport and buildings is to be established. Overall, this means a significant widening of the existing EU ETS to other polluting sectors and activities. These measures are accompanied by the revision of the Effort Sharing Regulation related to stronger emissions reductions targets for member countries in sectors that will remain outside the EU ETS (building, road, domestic maritime transport, agriculture, waste, and small industry sectors). In addition, six other revisions and amendments of existing regulations will be enhanced, accompanied by new initiatives that support zero-emissions technologies, finance investments in energy efficiency, clean mobility, and renewable energy, and are aimed at protecting EU-based businesses from competition from foreign energy-intensive companies [7].

Studies undertaken to date have shown that, due to the design of the EU ETS, which offers companies the choice between reducing their emissions and purchasing emissions from other companies depending on the carbon price, the system has been successful in meeting the goal of low financial burdens on EU industry [8]. However, scholars have not reached a consensus on its assessment. Ref. [4] found that the EU ETS saved about 1.2 billion tons of $\mathrm{CO}_{2}$ between 2008 and 2016, which represents almost half of EU governments' pledges under the Kyoto Protocol. Ref. [9] find it more cost-efficient than other policies. Nevertheless, the EU ETS system inspired the establishment of other carbon trading market mechanisms in the United States, Switzerland, Australia, Japan, New Zealand, and South Korea [10]. The EU measures implemented to date are signals towards further expanding such a system.

However, literature on the impact of carbon price risk on different sectors is rather scarce, although several studies indicate the need for carbon price risk management in the context of carbon market development [11-13]. It is rather surprising, in our opinion, that more research on the exposure of industries to carbon price risks has not yet been conducted. One possible explanation may relate to the difficulties of using EUA prices from different phases of the EU ETS, driven by different factors. We would also like to emphasize that existing research has tackled only one industry or sector, usually in one or a few countries. Thus, broader and more insightful views into the differences among industries and countries in terms of their exposure to carbon price risk have not been provided. Such a view is essential for further adjustments to carbon markets, including 
the EU ETS, and for the design of economic and energy policies that effectively impact GHG emissions. Our study enters this unexplored territory and offers the first integrated assessment of carbon price risk exposure of all economic sectors in EU member countries, thus supporting decision making in the field.

Given this context, the aim of our study was to assess the near-term carbon price risk of each economic sector for all EU Member States, in order to determine the overall potential impact of the greening measures on the economic sectors, and to identify the most affected sectors. The novelty of this study is in the application of risk management methodologies based on Value at Risk, which is usually used by financial institutions to gain a holistic view of their risk exposure, and particularly market risk exposure. Following this approach, we identify the sectors at risk of losing a high portion of their profitability, given their vulnerability to potential losses. Our analysis evidences the impact on each economic sector and highlights the differences between Western and Eastern EU countries, given their different levels of industrial development. In this manner, policymakers are equipped to better assess the energy transition risk across economic sectors and gain the knowledge needed to prioritize the support granted to each sector. Moreover, EU officials can distinguish whether a "one-size fits all" type of policy is suitable, or if greater space to maneuver should be left for each country by enhancing the adoption and enforcement of targets.

The next section of this paper describes the EU ETS system and the evolution of EUA prices to date. It also discusses the main results in the literature related to pricing models for the carbon market, and the exposure of specific industries or economic sectors to the volatility in EUA prices. Section 3 describes the data and methodology used, and Section 4 presents and discusses the results. The Section 5 summarizes the main findings and indicates further directions for research.

\section{Literature Review}

\subsection{International Agreements' Efficiency in Reducing GHG Emissions}

Countries' efforts in combating climate change and cutting GHG emissions following international agreements have had an effect on reducing pollution. Although the short period since the Paris Agreement's implementation limits academics' ability to judge its efficacy, several scholars have noted positive conclusions from the Agreement. For example, the gains in economic efficiency due to countries' cooperative implementation of the determined contributions in the Agreement were estimated by [14] to be a reduction in the global cost of achieving emissions goals in 2030 of approximately USD $300 \times 10^{9}$. If reinvested in supplementary emissions mitigation, this amount may add 9 billion tons of carbon dioxide per year, which is greater than the current 8 billion tons per year promised for 2030. Ref. [15] assessed the carbon dioxide emission efficiency and prospective emission reduction of nations under the Paris Agreement for the period 1991-2014. They concluded that China is the most important beneficiary, with an annual potential $\mathrm{CO}_{2}$ emission reduction of more than 2000 billion tons, but countries with different income levels exhibit dissimilar emission reductions. They also argued in favor of technological innovations that may improve carbon emission efficiency, particularly in lower-income countries. Ref. [16] contend that intensive stakeholder engagement, public awareness campaigns to explain why reforms in the field of GHG are necessary and how the public will benefit, and a slower pace of reform that gives consumers and businesses time to adjust, are factors that may help to improve the chances of successful decarbonizing reforms.

\subsection{The EU ETS System}

ETS is the first "cap-and-trade" system created in the world to reduce GHG emissions and is the core of the EU's ambition to promote emissions reductions in a manner that is cost-effective and economically efficient [6]. Based on the United Nations Framework Convention on Climate Change (UNFCCC) in 1992 and the subsequent Kyoto Protocol in 1997, the system debuted with a first pilot phase in 2005, which lasted until 2007, followed 
by two more completed phases (2008-2012 and 2013-2020), and a fourth phase that is currently in progress (2021-2030). The reduction in GHG emissions targeted by the EU ETS is based on two main components: a ceiling (cap) on the maximum quantity of emissions for economic sectors and industries, and the possibility of trading allowances in the form of one EUA for each ton of $\mathrm{CO}_{2}$ equivalent emitted by ETS-covered installations during a year.

The first two phases of ETS used national allocation plans, and EUAs were mostly allocated for free and based on grandfathering, i.e., historic emissions. The cap for allowances was reduced, and around 10\% were auctioned, instead of being freely allocated. Due to the economic crisis in 2008, which drastically reduced emissions following the decrease in economic activity, the surplus of allowances led to low carbon prices. Starting with phase 3 (2013-2020), several reform measures were imposed. The national allocation plans were replaced by a single, EU-wide cap on emissions and auctioning became the main method for allocating allowances. The ETS system widened to encompass the GHG emissions from power and heat generation, energy-intensive industrial sectors, and aviation. The fourth phase (2021-2030) established the aim of achieving a 43\% reduction in GHG emissions in 2030 compared to 2005. Several new measures were established when the EU ETS Directive came into effect from 2018 [17]. The number of emission allowances was set to decline by $2.2 \%$ annually, starting from 2021 , compared to $1.75 \%$ previously, and the volume of auctioned allowances stayed around $57 \%$, similar to the level in phase 3.

The enacting of the Green Deal also reinforced the EU ETS, with the aim of making Europe the first climate-neutral continent by 2050 and reducing the GHG emissions by $55 \%$ by 2030, compared to 1990 levels. Under the new legislative proposal in 2021 [7], the Commission will increase the reduction in emissions by capping them at a pace of $4.2 \%$ annually, adopting drastic measures in the aviation sector by 2027 , and including the emissions from the maritime sector in the existing EU ETS, thus covering two-thirds of the maritime transport emissions. At present, $41 \%$ of the EU's total emissions are covered by the ETS system. However, the EU intends to develop a similar emission trading system for other sectors in the economy, such as road transport and buildings, as an incentive for the transition to a cleaner environment. This will function from 2025 and will cap the emissions in the following year. These measures are accompanied by the revision of the Effort Sharing Regulation (ESR) and the Regulation on Land-Use, Land-Use Change, and Forestry (LULUCF). Therefore, the new revision raises national targets for GHG emissions under ESR from a reduction of $30 \%$ by 2030 to a decrease of $40 \%$ in the same year, compared to 2005 levels [7]. The measure covers the direct emissions of GHG from transport (excluding aviation and non-domestic shipping), buildings, agriculture, industrial installations (not covered by the EU ETS), and waste, in addition to non-combustion-related emissions from energy and product use. LULUCF is also enhanced by establishing targets for carbon removals by natural sinks and requiring national integrated climate change mitigation plans for the land sector.

The ETS was, however, criticized for its failure to deliver a carbon price that would incentivize the low-carbon transition [18]. One of the goals of the first phase of the EU ETS was the establishment of a price for EUAs. However, the publication of real-world emission data revealed that there was an excessive supply of EUAs, which led to a fall in prices; at the end of the phase, the price reached zero. During the second phase of the system, the Global Financial Crisis of 2007-2009 added to the additional credits that businesses could use [19] and led to another oversupply of EUAs. Prices fell to below EUR 7 and even close to zero during the crisis. The situation continued during the third phase, when the large oversupply of EUAs that were transferred from the second phase again led to a low EUA price, of between EUR 3 and 7. Consequently, the EU adopted so-called backloading, or postponement of the auctioning of 900 million EUAs, to the end of this phase [7]. Moreover, new measures were implemented in order to regulate similar situations in the future. In the fourth phase, the Market Stability Reserve (MSR) was established with the role of a central bank in dealing with liquidity. MSR will play the role of injecting or withdrawing emissions 
permits into or from the market, with the role of stabilizing the prices [4]. Following these measures, the prices started to increase [20]. Opinions about introducing a price floor to the EU ETS were advanced by [19-23]. Moreover, scholars have also pointed to the utility of the ETS carbon market for hedging portfolio risk [24-26]. An interesting point was made by [27], who observed that significant differences between the EU Member States can be identified in terms of ETS implementation, but their research covered only the first phase of the system. A recent scholarly contribution has also demonstrated that a cap adjustment can take place because of increased EU targets for renewable energy and increased energy efficiency, accompanied by policies aimed at eliminating coal from the energy mix at the national level; hence, it was estimated that emissions in the sectors covered by the EU ETS can diminish by $57 \%$ until 2030 [28].

\subsection{Carbon Pricing Models_-Drivers and Impact on Economic Sectors}

Because the specific goal of this study was to assess the near-term carbon price risk of each economic sector for all EU Member States, our research built upon several strands of existing and developing scholarly contributions. These are summarized here. The first research direction refers to pricing models for the carbon market, which first appeared in 2003, even before the EU ETS system began to operate. Ref. [29] reviewed various models of carbon pricing and estimated values of USD 3-74 and EUR 5-30 per ton of $\mathrm{CO}_{2}$ equivalent. After the EU ETS system began operations, researchers were in the position to use actual EUA prices for modeling purposes. The results have shown that models that capture asymmetries, excess kurtosis, or fat tails, and that consider different phases of carbon prices' return volatility, are better suited for the modeling of carbon prices (see, in this regard, [30-36]. Benz and Trück [30] focused on the short-term EUA price behavior in the EU, given its importance for determining the production costs of companies. The authors evidence the superior performance of AR-GARCH or regime-switching models in modeling these prices, which can be further used for VAR (Vector Autoregression) purposes. Ref. [37] argued strongly in favor of non-linear models for the forecasting and pricing of emissions, based on the investigation of spot and futures prices of EUAs during the second phase of trading using vector auto-regressive and GARCH-type models. Their results were supported by further investigations conducted by [38-40].

Second, research has revealed the complexity of the carbon pricing mechanism, in addition to the demand and supply for EUAs, with various drivers of EUA prices included in the pricing models. The research on these drivers expanded in 2007 due to the ease of observing the price formation in the EU ETS compared to Certified Emission Credits (CERs) and Emission Reduction Units (ERUs) under the Kyoto Protocol [41]. Refs. [42-44] were the first authors to investigate EUA prices in models that included weather (extreme temperature) and energy prices, and macroeconomic factors (equity dividend yields and premiums on speculative-grade bonds). Furthermore, among the supply side drivers of carbon prices, scholarly investigations included the institutional policies adopted by the European Commission in the area of GHG emissions [45]. Regarding the demand side, research shows that prices are linked to economic growth [19,46-48] and macroeconomic risk factors, including shocks in exchange rates [49], European industrial production [50], and surprises in the news related to economic activity and future economic advances [30]. Similarly, the demand for EUAs depends on weather conditions, in addition to solar and wind production of electricity [47] and Certified Emission Reductions (CERs). Ref. [51] also showed that the prices of other energy sources (crude oil, coal, natural gas, and electricity) influence carbon prices, and their results were confirmed by [52-54], among many others.

The third research direction relevant to this study is the impact of carbon price risk on economic industries and sectors. An intriguing matter for scholars was whether the carbon price level was effective enough to reduce $\mathrm{CO}_{2}$ emissions. Various researchers expressed skepticism, arguing that carbon prices in the EU ETS were too low, particularly compared to the social cost of carbon, and were thus not discouraging "business-as-usual capitalist growth" [55-58]. However, ref. [4] insisted that low carbon prices are compatible with 
decarbonization and are explained by an excessive supply of EUAs due to over-allocation, and by low demand resulting from changes in the behavior of businesses covered by the EU ETS. Moreover, as long as the EU ETS is seen by businesses as a credible institution supported by reliable regulatory policies, its role in promoting emissions reduction can be confirmed.

However, there is very little research that directly tackles the exposure of specific industries or economic sectors to the volatility in EUA prices, which is the subject of our study. One attempt in this area is that of [59], which addresses the road transportation industry in Italy and investigates the reduction in uncertainty associated with emissions. By applying metrics used in the financial industry, the authors show that the design of strategies aimed at reducing $\mathrm{CO}_{2}$ emissions can be enhanced by accounting methods that consider uncertainty in emission data. Similar results were obtained by [60] in a study of vehicle emissions in Ireland, by [61] for transportation in Brazil, and by [62] for transportation in Istanbul, Turkey.

Ref. [63] were among the first authors to analyze the constraints that businesses would face due to the presence of fossil fuels in their inputs and to pollution in their outputs. Reviewing the literature in the field, the two scholars concluded that companies' specific exposure to carbon risk is driven by their dependency on carbon-based energy and materials, but the financial consequences are unequal among and within economic sectors. More focus was placed on the matter of carbon exposure of economic sectors by [64], who used an asset pricing model to assess the influence of carbon price risks on European utilities' cost of capital between 2005 and 2010. The authors discovered an asymmetrical distribution of carbon price risks among utility firms, and a significant impact for the latter, i.e., an increased cost of capital, was only found on utilities using a fuel mix having high carbon emissions. In addition to fuel mix, the paper demonstrated that the main drivers of European utilities' exposure to carbon price risk are permit allocation rules and businesses' decisions to invest in less polluting technology. Ref. [65] conducted a similar exercise on American electricity producers using a carbon-based input-output framework. Results revealed that increased carbon constraints may lead to heightened financial risk of these businesses, which can be mitigated by significant investments in renewable energy technologies.

In this context, it is interesting to note the empirical evidence, in the form of higher returns without a significant increase in risk, in favor of a market-based recognition by investors of European utilities' strategies towards decarbonization [66,67]. Other scholars have also revealed the presence of a statistically significant "carbon premium" for firms with high carbon emissions and higher exposure to carbon risk [68-70]. Moreover, institutional investors that manage large asset portfolios were more concerned about the environmental exposure of companies they hold in these portfolios and diminished the weights allocated to high-emission companies [71]. Similar results showing that institutional investors have moderate exposure to carbon risk and have gradually reduced this exposure over time, were reported by [72,73]. They contrast earlier studies that suggested a lack of interest among institutional investors in carbon exposure as a selection criterion for assets under their management [74].

As mentioned above, the specific topic of carbon price risk and its impact on industries was only of interest for a few scholars. For example, refs. [75,76] were concerned about the influence of carbon price risk on businesses' investment decisions and showed that, counter to expectations, these risks were considerable even for low-carbon technological options. Moreover, several authors evidenced the increased importance of carbon price risk management given the development of carbon markets [11-13]. Ref. [77] argued that export-oriented economic sectors should be more affected by carbon price risks as these risks would negatively impact their competitiveness in international markets. However, the greater size of these sectors in the economy and the lower carbon intensity would represent, according to the two authors, good mitigating channels for the sectors' carbon price risk exposure. 


\section{Materials and Methods}

The purpose of our analysis was to quantify the near-term carbon price risk of each economic sector for all $27 \mathrm{EU}$ Member States. We partitioned these states into two categoriesEastern and Western countries-to observe if there are dissimilarities between the typically more developed Western nations and the Eastern nations. The Eastern category comprises 13 countries: Bulgaria, Czechia, Estonia, Greece, Croatia, Cyprus, Latvia, Lithuania, Hungary, Poland, Romania, Slovenia, and Slovakia. The 14 Western countries are Belgium, Denmark, Germany, Ireland, Spain, France, Italy, Luxembourg, Malta, Netherlands, Austria, Portugal, Finland, and Sweden. The UK is excluded because it has not been part of the EU since 1 January 2021. We do not add Greece to the Eastern category merely due to geography. Greece, although part of the Eurozone and closer to Western states in terms of socioeconomic development, has faced a prolonged economic downturn, while other Eastern nations have recovered from the financial crisis and resumed their growth path. Thus, the development gap between Greece and the other Eastern countries has narrowed. Greece's reliance on international tourism in the pandemic context may further compound this catching-up effect.

We used Eurostat data for GHG emissions and gross value added (GVA) at industry and country levels. The GVA represents the value of an industry's output at basic prices less intermediate consumption, in current prices, and is calculated before consumption of fixed capital (for a full definition from Eurostat see: https:/ / ec.europa.eu/eurostat/web/ products-datasets /- / teina404_r2 (accessed on 19 October 2021)). This can be considered a good measure of an industry's profitability. The fact that it only takes into account the value of intermediate inputs is a useful feature as it allows for better comparability between countries. Other elements that contribute to net profit, such as taxation, can differ significantly across countries. Ref. [78] use this indicator in their analysis of the relationship between economic structure and achievement of sustainability goals for EU countries. Our purpose was not to conduct a comprehensive risk assessment, as undertaken by individual companies that have access to their own detailed internal data. Instead, we aimed to provide policymakers with a high-level overview of carbon price risk at the sector level, across the EU.

Dividing GHG emissions by GVA would yield a GHG intensity metric. This is useful but does not provide information regarding the financial exposure of each sector to carbon price risk. To achieve this, we used the Value at Risk (VaR) methodology typically employed in risk management. VaR is a statistical measure that relates the size of potential loss in a portfolio over a target period to its probability of occurrence. It is computed by estimating the probability distribution of gains and losses over the respective period and then identifying the portion of the downside which corresponds to the chosen probability level [79]. For example, a VaR of USD 5 million over a ten-day period at a confidence level of $90 \%$ means that there is a $90 \%$ probability that no more than USD 5 million will be lost over a ten-day period. Conversely, there is a 10\% probability that more than USD 5 million will be lost over the same period. The main advantages of the VaR methodology are its flexibility - it can be computed at different probability levels over different periods—and the ease of conceptual understanding. The latter, especially, may be the main reason for its widespread use in corporate circles. Decisionmakers in both the private and public sectors need to assess risks based on quantitative tools that they can understand (i.e., that are not so-called "black boxes"). Other methodologies such as scenario planning may also be suitable, but constructing narrative scenarios is a complex task with a potentially subjective outcome. The quantitative nature of VaR eliminates this subjective aspect. Nevertheless, depending on the parameters, the data used, and method of estimation, the results of the analysis may show an extremely large value. For this reason, we urge that any further application of this methodology consider the nature and purpose of the ETS system and its constraints. These constraints need not be explicit, as it would be reasonable to assume that aberrantly high carbon prices over a long period will not be tolerated by policymakers, leading to interventions in the market. Some elements of scenario planning may be useful 
in this regard, when considering the interactions between carbon markets and the rest of the economy. Therefore, we do not advocate for the blind use of a single tool, but we argue that it can provide useful insight, particularly in times of high volatility.

In the present case, the VaR was computed for the carbon price under the EU ETS. We used the daily spot price for emissions allowances covering the period October 2012August 2021, sourced from Thomson Reuters. The data is presented in Figure 1. It should be noted that the application of the VaR methodology differs from the usual case because we view the problem from the perspective of industrial sectors. An investor is interested in the loss that may be experienced by holding a portfolio or a single asset, whereas emissions allowances represent a cost for enterprises and, the higher the price, the higher the cost. Therefore, instead of computing the downside risk, we compute the upside risk. For this purpose, two methods were employed. The first is a simulation, based solely on historical data, whereas the second consists of estimating an ARMA-GARCH model and conducting simulations using the model's parameters. For each of these methods, we use log returns and finally transform the obtained VaR returns back to prices by applying these to the last price available (for 17 August 2021). The entire analysis was carried out using MATLAB. Log returns are presented in Figure 2. To ensure compatibility, the VaR level was set at $90 \%$ with a 91-day time horizon for both methods. The VaR level can be adjusted with higher confidence levels, but this may lead, in our opinion, to higher price estimates that may prove unrealistic. The period represents the remaining working days and applying the cumulative VaR returns to the last price yields a price estimate for the end of the year. Covering an entire year is reasonable given the annual compliance cycle. Companies may purchase allowances throughout the year to cover their actual and forecast emissions but are required to surrender these only once the following year.

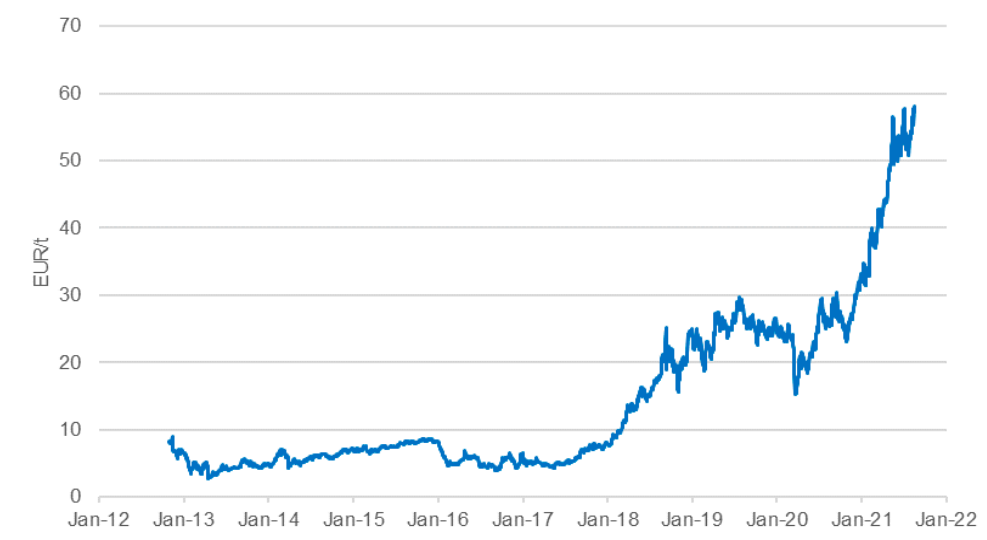

Figure 1. Daily emissions allowance spot prices (EUR/t). Source: Authors' representations.

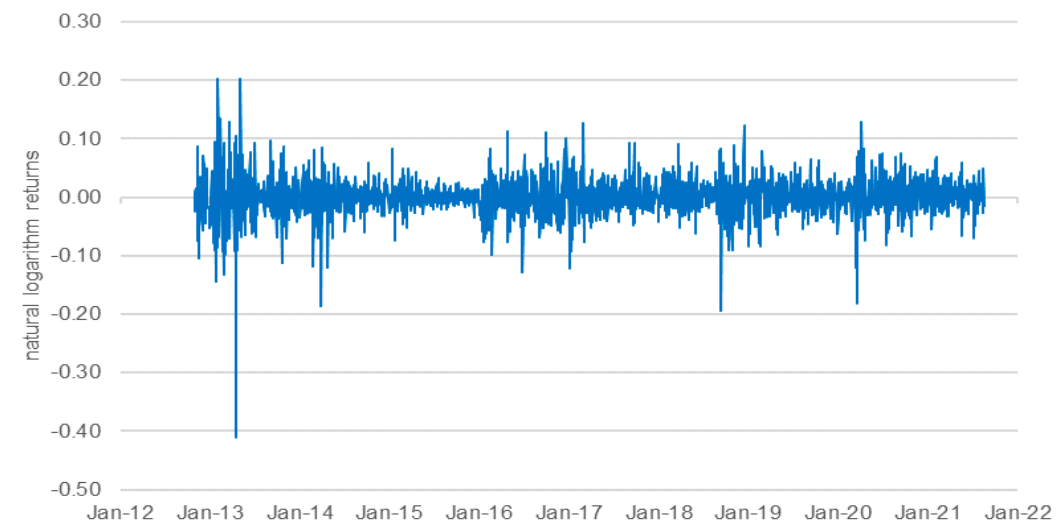

Figure 2. Daily emissions allowance log returns. Source: Authors' representations. 
For the historical simulation, we restricted the data used to the fourth phase of the ETS, which began on 1 January 2021, and will run up to 2030. Our dataset extends to 17 August 2021, yielding a sample of 159 observations. This is greater than the 91-day time horizon. To obtain a sample of 91 observations, we conducted random sampling with replacement. Further bootstrapping of the derived sample yielded 2000 samples. For each, the total return over the period was obtained by the addition of each daily return, keeping in mind that we used log returns. We recorded the $90 \%$ VaR from the 2000 returns. The process was repeated 2000 times. Finally, the 2000 VaR estimates were averaged. The simulation can be conducted on a larger sample or even on the entire dataset. Nevertheless, it is likely that, in this case, the more recent history may yield more useful information.

The ARMA-GARCH model was applied to the entire dataset. Before doing so, we determined whether a unit root was present (i.e., whether the series is non-stationary) via the augmented Dickey-Fuller (ADF) and Phillips-Perron (PP) tests. Results for both the original price series and $\log$ returns are provided in Table 1. For the former, the tests fail to reject the null hypothesis of a unit root, whereas for the latter the null hypothesis is rejected. This confirms the observations of Figures 1 and 2, i.e., the price exhibits an upward trend, whereas returns appear to fluctuate around the mean. This is one reason why using log returns is preferred for use in the analysis.

Table 1. Unit root tests.

\begin{tabular}{ccccc}
\hline & ADF Test Statistic & $p$-Value & PP Test Statistic & $p$-Value \\
\hline Price level & 3.1269 & $>0.99$ & 3.0559 & $>0.99$ \\
Log returns & -35.6576 & $<0.01$ & -46.1573 & $<0.01$ \\
\hline
\end{tabular}

We proceeded to fit an ARMA $(p, q)$ model to the log-returns data. This assumes that the data is generated by an autoregressive (AR) process of order $p$ and a moving average (MA) process of order $q$. The general equation is given below:

$$
y_{t}=c+\sum_{i=1}^{p} \varphi_{i} y_{t-1}+\sum_{j=1}^{q} \theta_{j} \varepsilon_{t-j}+\varepsilon_{t}
$$

where $c$ is a constant, and $p$ and $q$ are the autoregressive and moving average orders, respectively. $\varphi$ and $\theta$ are autoregressive and moving average coefficients, respectively, and $\varepsilon$ is the error term. In simply terms, the model assumes that the value of variable $y$ at time $t$ is a function of its past values (the autoregressive process) and past errors (the moving average process).

Models with different combinations of $p$ and $q$ orders were fitted and the most suitable one was selected based on the Bayesian information criterion (BIC). The BIC provides a metric for model selection that considers both goodness of fit and parsimony by penalizing models according to the number of parameters. Of two models which fit the data equally well, the one with fewer parameters would be preferred. We used the BIC instead of other information criteria, such as the popular Akaike information criterion (AIC), because it has been found to perform better and tends to choose more parsimonious models [80]. The criterion indicates that an $\mathrm{AR}(2)$ model is the best choice (i.e., it has the lowest BIC value)see Appendix A. However, ARMA models assume that the error term is homoscedastic, which is unrealistic for many financial time series that exhibit conditional heteroscedasticity. This feature, also known as volatility clustering, can be observed in Figure 2 as alternating periods of high and low volatility. To check if this is indeed the case, we conducted Engle's autoregressive conditional heteroscedasticity (ARCH) test [81]. If volatility clustering is present, then volatility in the current period should be related to volatility observed in previous periods; that is, it should fit an autoregressive model. The null hypothesis of the test is that no conditional heteroscedasticity is present in the residuals (computed by subtracting the mean), whereas the alternative is that the series of residuals is described 
by an $\operatorname{ARCH}(L)$ model, where $L$ is the number of lagged error terms. The model is detailed below:

The error terms are assumed to be generated by a random variable and a timedependent standard deviation:

$$
\varepsilon_{t}=\sigma_{t} z_{t}
$$

where $\varepsilon_{t}$ is the error term at time $t, \sigma_{t}$ is the standard deviation at time $t$, and $z_{t}$ is an independent and identically distributed process with zero mean and unit variance. It is assumed to follow a Student's t distribution as this better captures the characteristics of financial series, namely, the higher chance of extreme values. $\sigma_{t}^{2}$ is modeled as follows:

$$
\sigma_{t}^{2}=a_{0}+\sum_{i=1}^{L} a_{i} \varepsilon_{t-i}^{2}
$$

where $a_{0}>0$ and $a_{i} \geq 0$. The null hypothesis is that ARCH effects are absent and therefore $a_{i}=0$ for all $i$. Results of the test with one lag $(L=1)$ suggest that the null hypothesis should be rejected ( $p$-value $<0.001$ ) in favor of the $\mathrm{ARCH}(1)$ alternative.

The generalized autoregressive conditional heteroscedastic $(\mathrm{GARCH})$ model is an extension of ARCH developed by [82]. Financial time series may require a high number of ARCH lags to be modeled effectively. The GARCH specification overcomes this by allowing the conditional variance to be a function of past error terms and past conditional variances, resembling an adaptive learning mechanism. Thus, for a $\operatorname{GARCH}(L, M)$ model, Equation (3) becomes:

$$
\sigma_{t}^{2}=a_{0}+\sum_{i=1}^{L} a_{i} \varepsilon_{t-i}^{2}+\sum_{j=1}^{M} b_{j} \sigma_{t-j}^{2}
$$

where $a_{0}>0, a_{i} \geq 0$, and $b_{j} \geq 0$. Equation (2) remains unchanged. Ref. [83] found that a GARCH specification with a Student's t error distribution performs better than the Gaussian variant. Therefore, we continued to assume that $z_{t}$ follows a Student's $t$ distribution.

We compared several GARCH (L, M) combinations, and two GARCH variantsexponential GARCH [84] and GJR [85]. These attempt to capture asymmetries between returns and volatility encountered in financial markets. The former considers the sign of the changes in the error terms, whereas the latter only gives additional weight to negative changes. Based on the lowest BIC value, we selected an $\operatorname{AR}(2)-G A R C H(1,1)$ model. The estimated parameters are presented in the Table 2, where DoF represents the degrees of freedom parameter, which needs to be estimated due to the use of Student's $t$ distribution.

Table 2. Parameter estimates for AR(2)-GARCH(1,1) model.

\begin{tabular}{cccc}
\hline \multicolumn{4}{c}{ Conditional Mean-AR(2) } \\
\hline Parameter & Estimate & Standard error & $p$-value \\
\hline Constant & 0.0014 & 0.0005 & 0.0026 \\
AR(2) & -0.0407 & 0.0210 & 0.0520 \\
\hline & Conditional Variance-GARCH(1,1) & \\
\hline Parameter & Estimate & Standard error & $p$-value \\
Constant & $<0.0001$ & $<0.0001$ & 0.0023 \\
\hline GARCH(1) & 0.8965 & 0.0126 & 0 \\
ARCH(1) & 0.1012 & 0.0142 & $<0.0001$ \\
DoF & 5.2025 & 0.5730 & $<0.0001$ \\
\hline
\end{tabular}

A total of 2000 simulations were conducted for a 91-day period based on the fitted model. As before, daily returns were summed, and the $90 \%$ VaR was recorded. A summary of the simulation output is presented in Figure 3. 


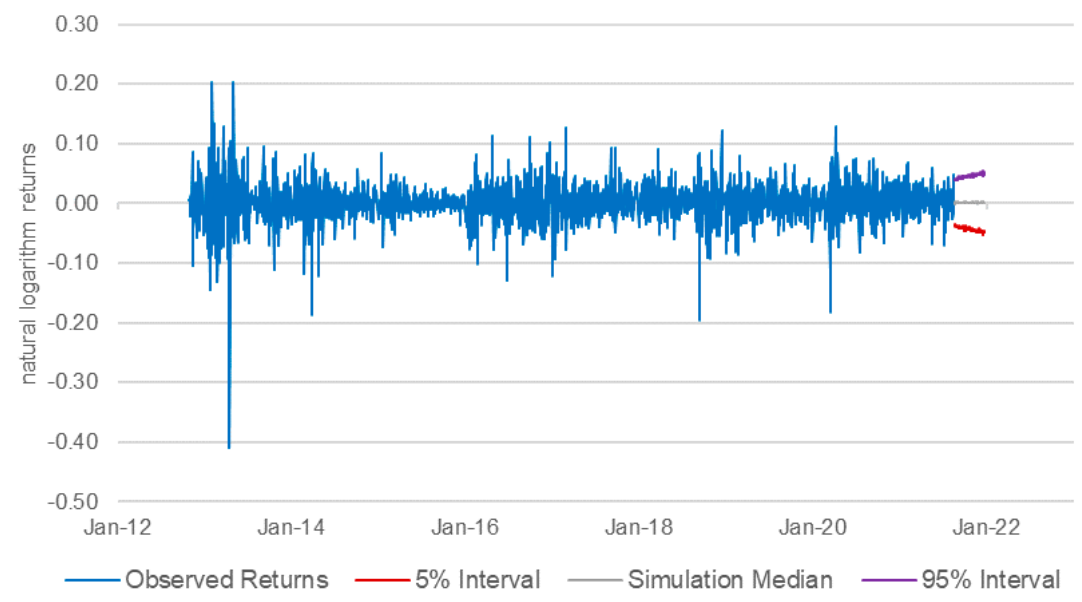

Figure 3. Simulation results. Source: Authors' representations.

\section{Results and Discussion}

The 90\% VaR 91-day cumulated log returns obtained via the two methods were applied to the last price available, yielding a carbon price of $103.6 \mathrm{EUR} / \mathrm{t}$ for the historical simulation method and $88.1 \mathrm{EUR} / \mathrm{t}$ for the $\mathrm{AR}(2)-\mathrm{GARCH}(1,1)$ model simulation. The fact that the historical simulation price is higher is unsurprising because, in this case, only the data for January-August 2021 — a period marked by significant price growthwere used. We used the same approach to estimate the 250-day VaR returns and applied these to the price at the start of 2021. Interestingly, the differences do not appear to be especially large, particularly for the model simulation. The carbon price is $124.5 \mathrm{EUR} / \mathrm{t}$ and 84.4 EUR/t for the historical and model simulation methods, respectively. This is because the price recorded on 17 August 17 was 74\% higher than that at the beginning of the year. Therefore, applying this methodology when significant price increases are expected can prove highly informative.

The two price estimates were applied to the emissions quantities for every sector of every EU Member State to quantify the potential costs. This was then divided by the sector's GVA to yield what may be called a value erosion metric. The ETS is currently applied mainly to large industrial installations; however, because the ultimate goal is to reach net-zero emissions it is reasonable to assume that all sectors will be affected. Our purpose was to provide a holistic image of the carbon price risk for the entire economy. The data was averaged over three years (2017-2019) because some installations may be offline in some years and other factors may impact the results recorded in a particular year. Averaging over a longer period may fail to fully capture potential carbon efficiency gains in various sectors. We excluded the 2020-2021 period from the analysis given the impact that the coronavirus pandemic had on most economic sectors, which might distort the results. Emissions quantities are restricted to the three gases currently covered by the ETS - carbon dioxide $\left(\mathrm{CO}_{2}\right)$, nitrous oxide $\left(\mathrm{N}_{2} \mathrm{O}\right)$, and perfluorocarbons (PFC), measured in $\mathrm{CO}_{2}$ equivalent terms.

As expected, the emissions cost to GVA ratio for a number of sectors is less than one percent. These sectors comprise high-value services such as financial intermediation and legal services; technology and telecommunications services; trade; and other sectors with negligible emissions. We do not report the results for these, but they are available from the authors if of interest. Figure 4 highlights the results for the main sectors at the EU27 level. The energy supply sector appears to be the most exposed, followed by agriculture, transportation, and mining. Nevertheless, caution should be used in interpreting the results as some sectors face greater international competition than others. For example, electricity may be imported but there are significant infrastructure limitations. Without pressure from lower-cost producers elsewhere, European companies will likely pass the costs along the value chain, to ultimately reach the final consumer. In a closed system, this may be sustainable if the European Commission and the governments of Member States allocate 
the extra income to vulnerable consumers and various projects. However, when combined with high energy prices, governments are likely to put pressure on energy companies through taxation or price caps, leading to erosion of profits. Therefore, the potential losses may not be as high as those shown in Figure 4; nonetheless, they cannot be assumed to be zero.

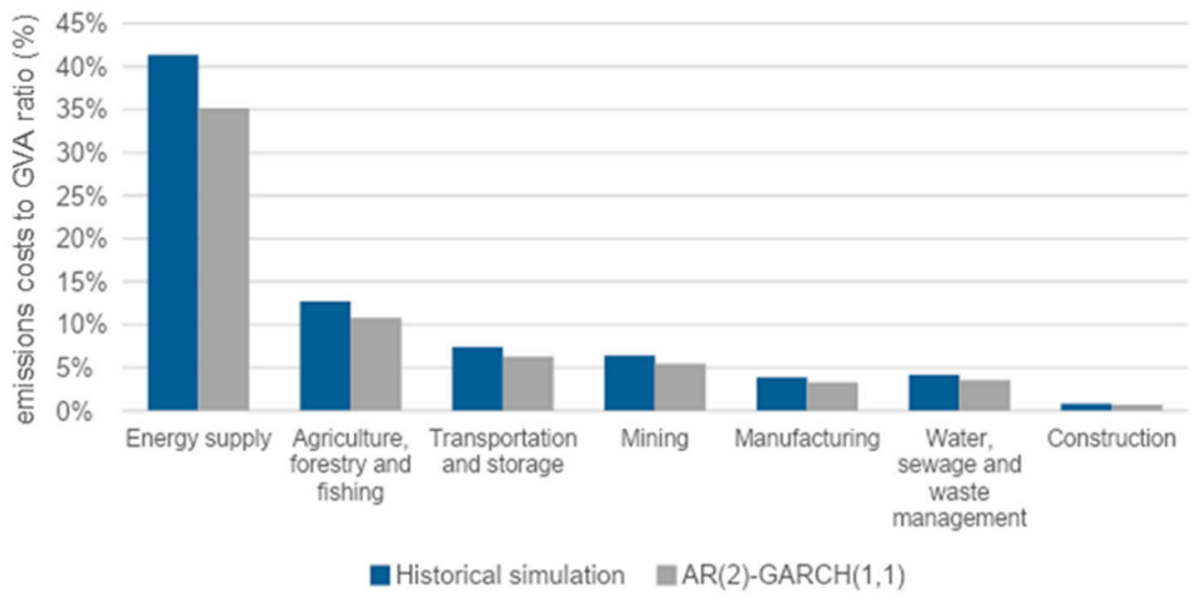

Figure 4. Potential emissions costs to GVA for the EU27 main sectors. Note: Mining includes quarrying and oil and gas extraction. Source: Authors' representations.

The remainder of the analysis uses the historical simulation price. The disaggregated results from Figures 5 and 6 show significant heterogeneity across countries. This is partly explained by the diversity of the economies under study. Their GDP per capita in 2019, according to Eurostat data, ranged between EUR 8800 (Bulgaria) and EUR 100,900 (Luxembourg), with an EU27 average of EUR 31,300. Furthermore, large demographic variations are also present, because three countries have more than 50 million inhabitants (Germany, France, and Italy), whereas three have less than one million inhabitants (Cyprus, Luxembourg, and Malta).

Nevertheless, one pattern can be easily observed-the ratio for the energy supply sector in Eastern nations is consistently high, in some cases exceeding 100\%. Western states are faced with the same problem but to a lesser extent. This is unsurprising given that Europe is still largely dependent on fossil fuels. The task of explaining the differences between countries is far easier in this case as performance is heavily dependent on the energy mix. As such, the low values registered by France and Sweden are largely due to a high share of emissions-free sources in power generation (renewables and nuclear). Calculations based on Eurostat data indicate that, in 2019, approximately $89 \%$ of net electrical output in France came from these sources: 69\% nuclear, 11\% hydropower, 6\% wind, and 2\% solar. For Sweden, the share stood at approximately $90 \%$ : 39\% nuclear, 39\% hydropower, 12\% wind, and less than 1\% solar. This is in stark contrast to some Eastern European countries such as Poland, Cyprus, and Estonia, where power generation is based on fossil fuels-their share in 2019 amounting to approximately 88\%, 91\%, and 88\% for each country, respectively. For the entire EU27, the share of fossil fuels was $44 \%$, and the remainder was spread among zero-emissions sources: $26 \%$ nuclear, $12 \%$ hydropower, $13 \%$ wind, and $4 \%$ solar.

It is also important to note that GHG emissions are only one part of the ratio and do not fully explain the outcome in some cases. Bulgaria is among the weakest performers with a ratio above $100 \%$ despite its dependence on fossil fuels being on par with the EU27 average (approximately 46\%). A potential explanation is that the GVA outcome in the energy sector is highly dependent on the regulatory environment. Moreover, in Eastern Europe, the government has a high degree of ownership and control over the energy sector. This is evident in Bulgaria as most assets are administered by the state-owned company, Bulgarian Energy Holding. These include the country's nuclear power plant, a coal plant and related mining operations, and hydropower plants. A recent commentary from ratings agency 
Fitch highlights the corporate governance limitations resulting from the complex structure and low financial transparency, in addition to the weak regulatory framework, with market liberalization still in progress (https:/ / www.fitchratings.com/research/corporate-finance/ fitch-rates-bulgarian-energy-holding-upcoming-eurobond-bb-exp-12-07-2021 (accessed on 21 October 2021)). According to its financial statements (which can be found on the company's website: https://bgenh.com/en/page/55/Financial-reports.html (accessed on 21 October 2021)), Bulgarian Energy Holding registered a net loss in 2018 of BGN 261 million (approximately EUR 133 million).

The potential ramifications of the East's high exposure are difficult to accurately discern. In other sectors, given privately owned assets, one may expect a rash of bankruptcies. However, the energy sector is usually deemed by governments to be of strategic importance. An abrupt change leading to high energy security risks is clearly undesirable at both national and EU levels because blackouts can severely undermine popular support for the energy transition project. A likely outcome is a continued functioning of part of the existing assets at reduced capacity or as a backup throughout the transition period. The extent of this will depend on the speed with which new solutions are implemented and EU policy.

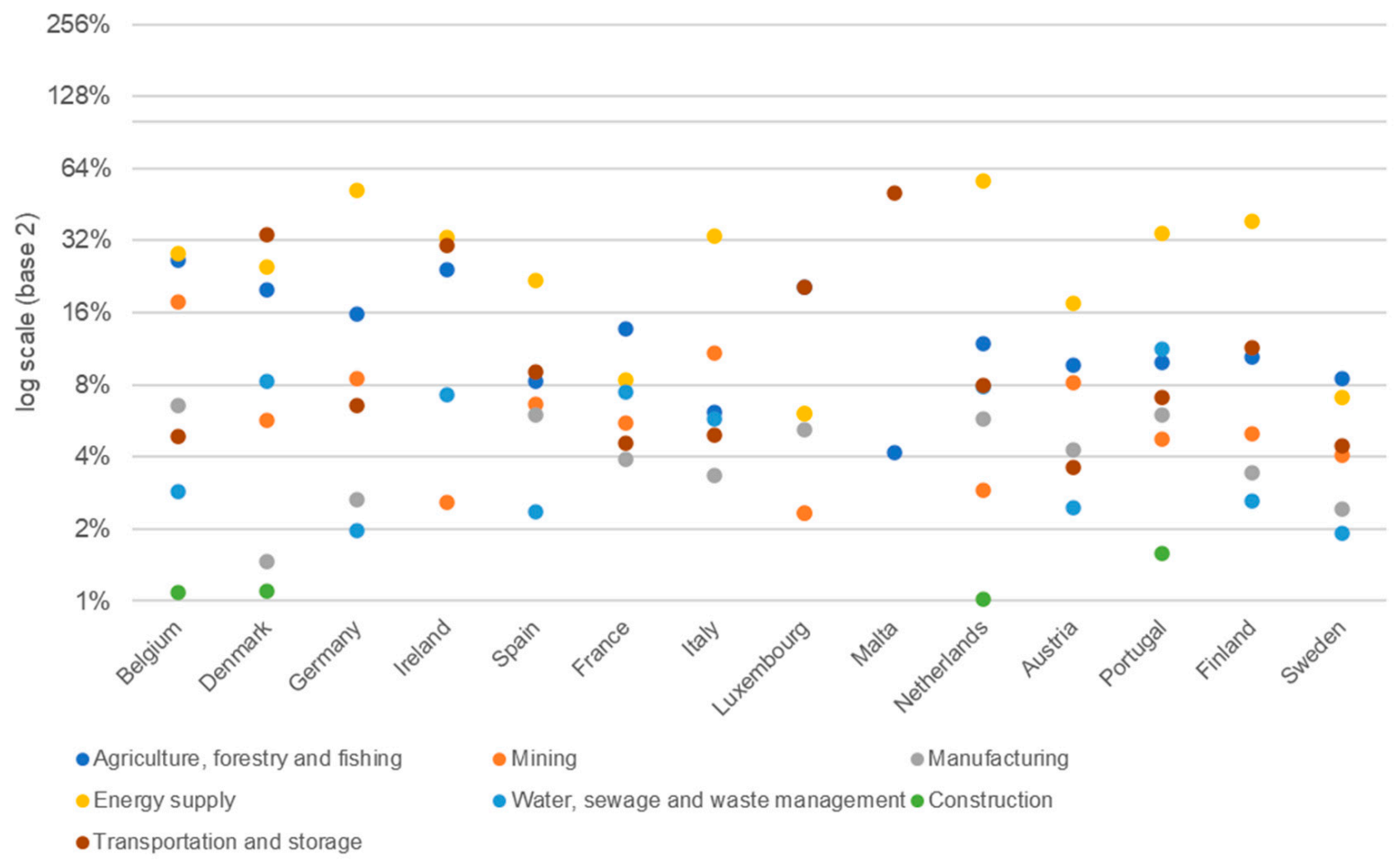

Figure 5. Potential emissions costs to GVA for main sectors across Western Europe. Source: Authors' representations.

Figure 7 shows that the aggregated GHG emissions across industries are, in some cases, much higher in the West compared to the East. Given that emissions are directly-although not perfectly-correlated with output, this gives an indication of the size difference between the two groups. Results for industrial sectors are presented in Figures 8 and 9. As before, we exclude those with extremely low values (available from the authors upon request). Differences between Eastern and Western countries may be due to the relative size of the sectors. In some of the smaller countries, entire industries are non-existent and those that do exist can be expected to be relatively small compared to those of larger economies. 


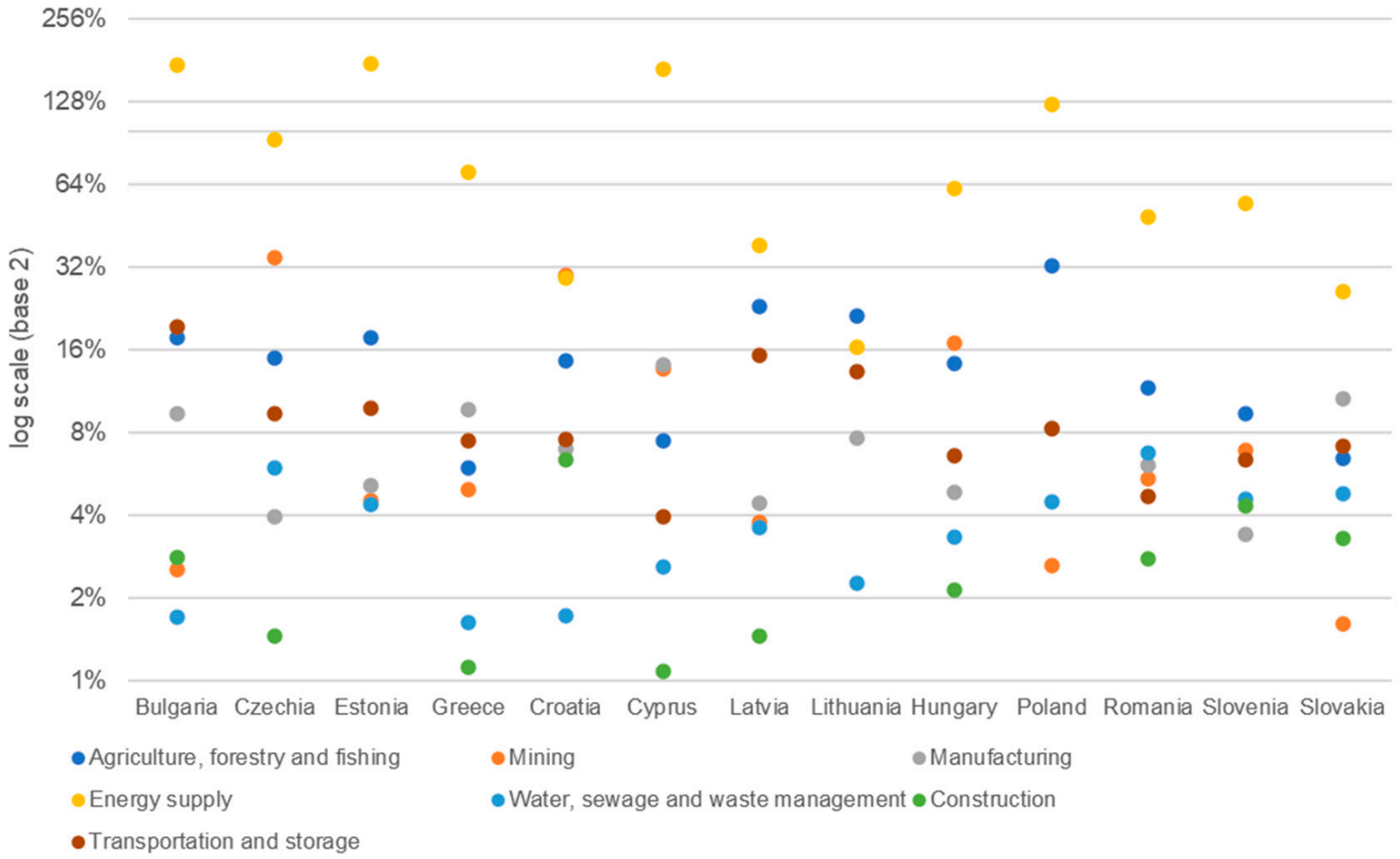

Figure 6. Potential emissions costs to GVA for main sectors across Eastern Europe.

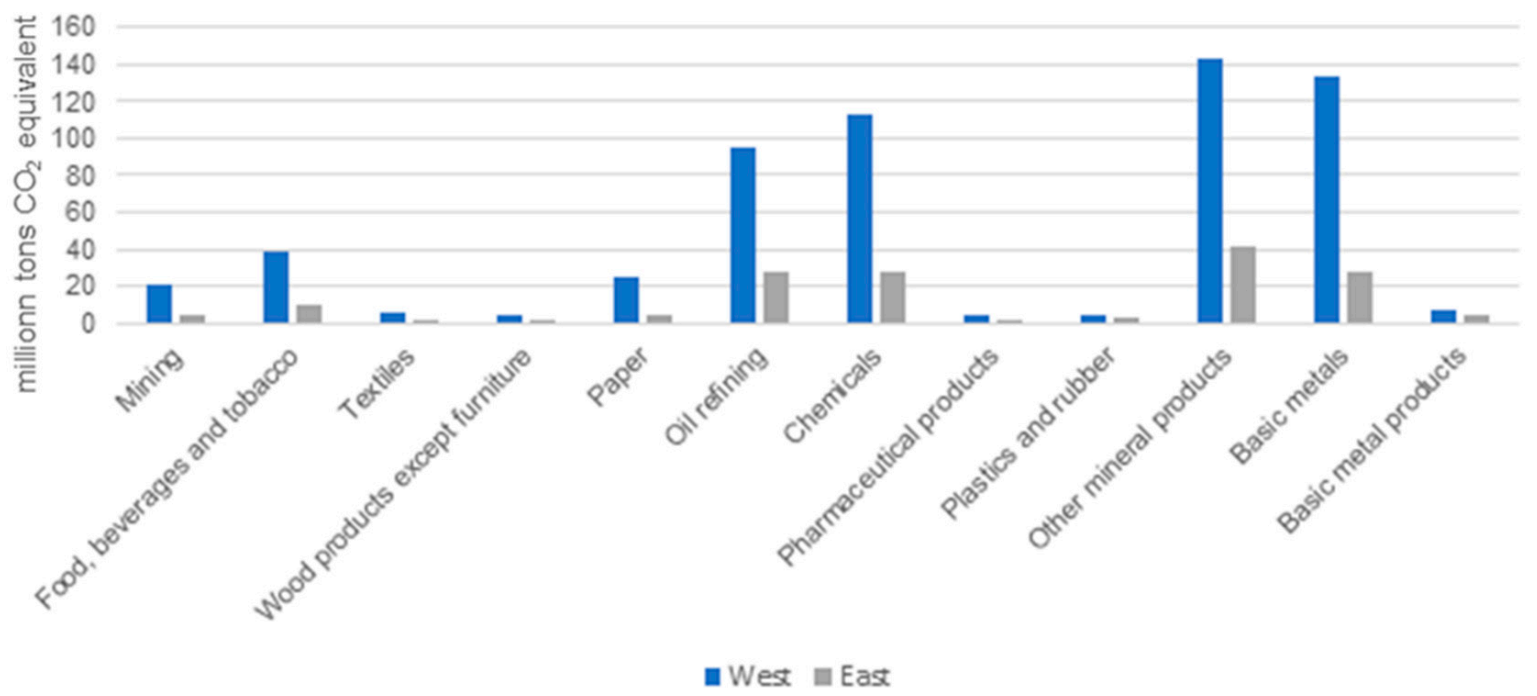

Figure 7. Aggregated GHG emissions across industrial sectors.

The small size of an industrial sector may lead to large deviations in the indicator from values registered for countries where the respective sector is large, because the exposure to idiosyncratic factors is greater. For example, if an entire sector is represented by a single plant, the result reflects only the characteristics of that plant, such as potential underperformance in terms of emissions and efficiency due to age and lack of investments, and any other particular circumstances relating to it (e.g., a worker strike or technical difficulties). Ref. [86] also found that energy demand varies over time across sectors. This may explain the large values registered for Cyprus' other mineral products sector or Slovakia's basic metals sector. For the latter, this does indeed appear to be the case because, according to press reports, the country's steel manufacturer, U.S. Steel Košice, cut its output in 2019 and announced layoffs. This explains why Slovakia's GVA for this sector 
fell by $39 \%$ in 2019 compared to 2018 . Unfortunately, detailed data at the plant level across European industries is lacking, making a comprehensive assessment of the exact causes of the outcome for each country and industry extremely difficult. This is outside the scope of the current study, but the analysis does highlight the sectors and respective countries that may warrant a more detailed analysis.

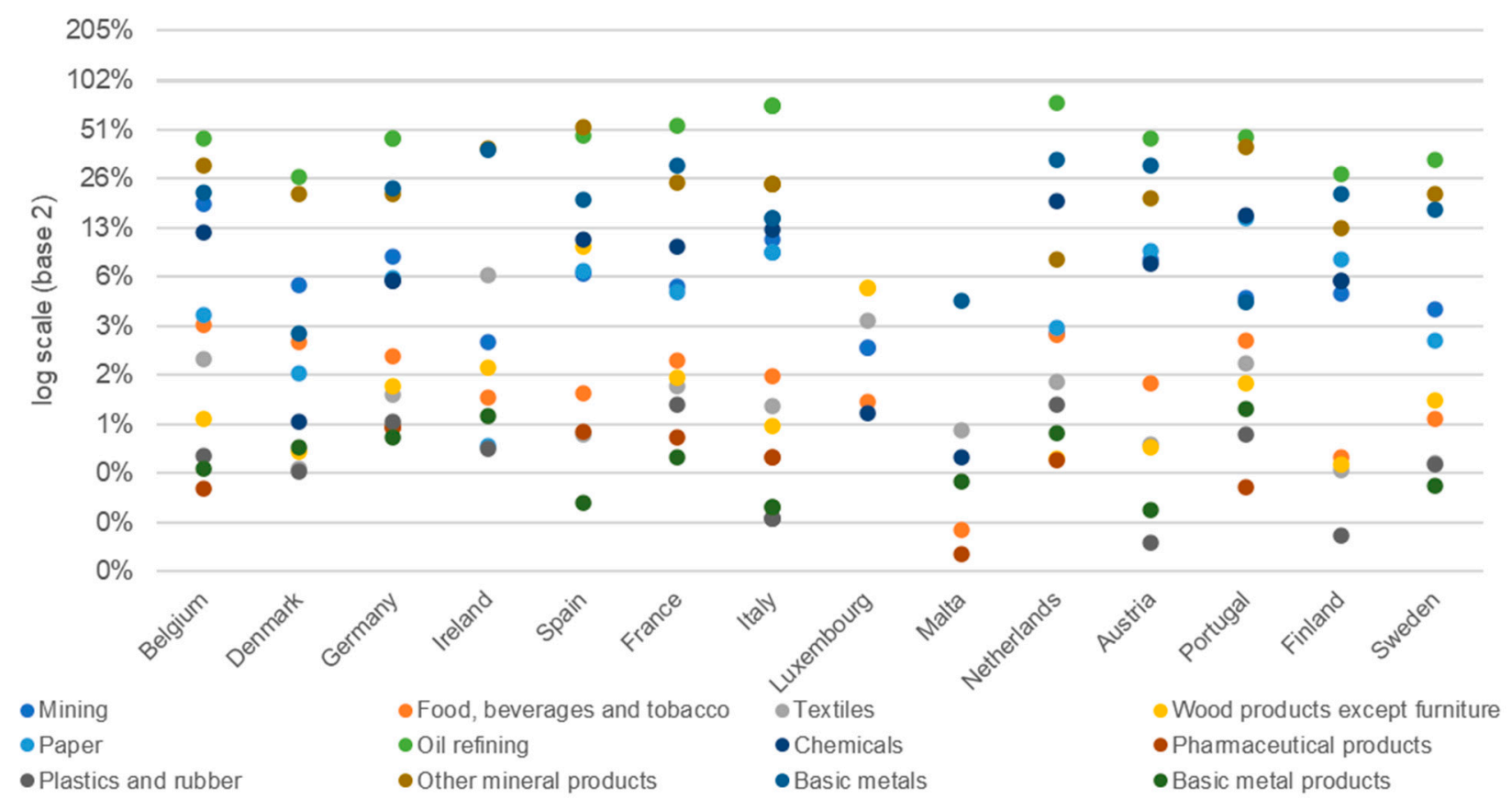

Figure 8. Potential emissions costs to GVA for main industrial sectors across Western Europe. Note: Mining includes quarrying and oil and gas extraction.

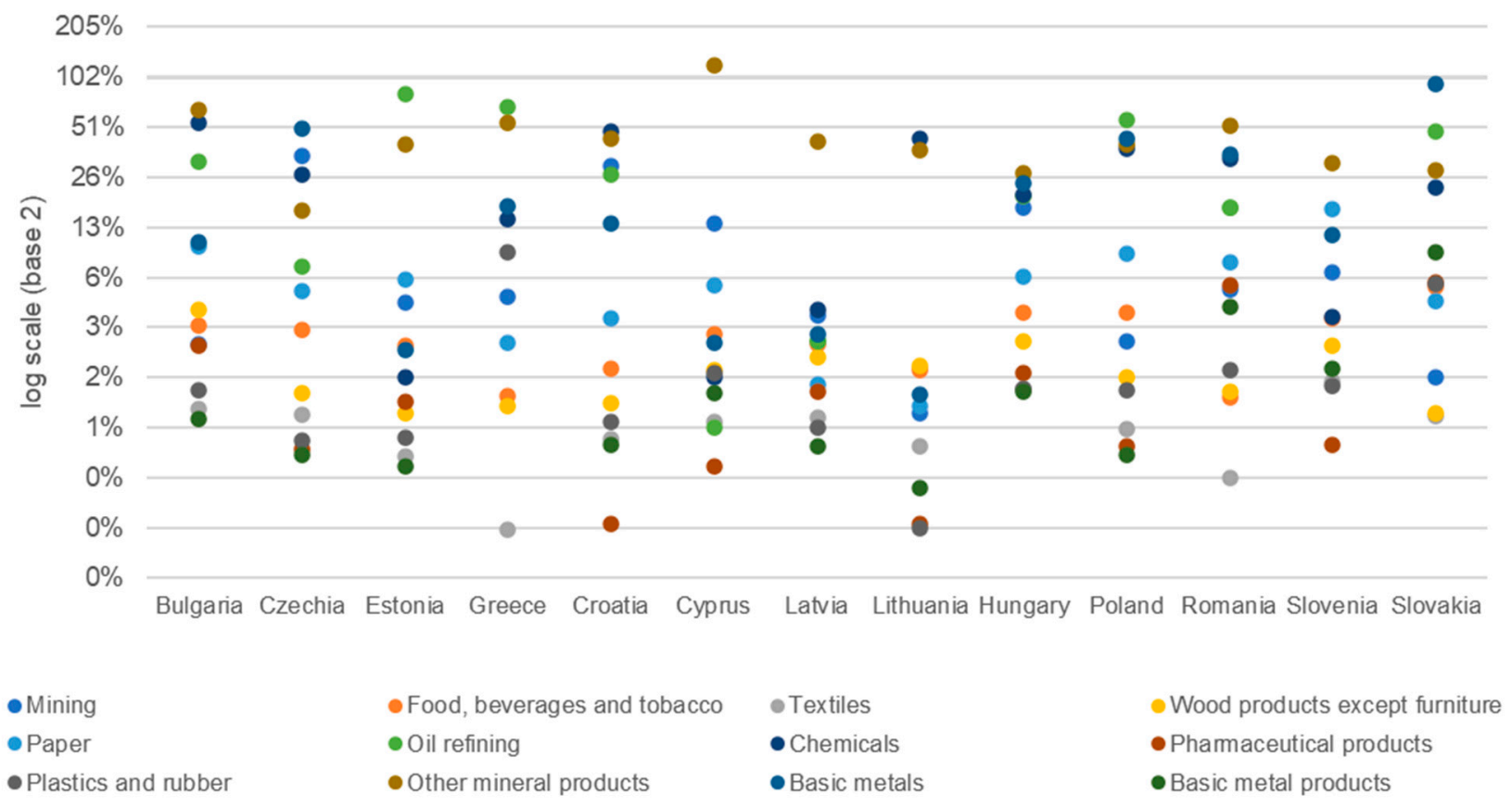

Figure 9. Potential emissions costs to GVA for main industrial sectors across Eastern Europe. Note: Mining includes quarrying and oil and gas extraction.

To gain a clearer picture of the differences between Western and Eastern countries, Figure 10 provides a weighted average of the ratio for each sector, with GHG emissions 
used as weights. The immediate observation is the high ratio recorded by the refining sector for both groups, highlighting the vulnerability of oil refining to the energy transition. This is not surprising because a large amount of refining capacity has been shuttered across Europe in recent years as competition from low-cost producers in the Middle East and elsewhere put pressure on margins. Nevertheless, the striking feature is that the two groups are close to each other, with the East even performing slightly better. This is likely the result of the sector's restructuring, which eliminated the least competitive units across all countries. The chemicals sector appears to fare better on average, but a large divide can be observed between the East and West. Note that this sector encompasses a wide range of chemical manufacturing processes and is not limited to products obtained from petroleum refining, which may explain the high heterogeneity across countries. Moreover, it may be the case that Eastern Europe has been slower to restructure this sector and may focus on lower value products. This shows that development along the chemicals value chain may be insufficient for mitigating the carbon risk. The other mineral products sector is also highly exposed in both the East and West. This is because it includes cement manufacturing, the production process of which releases $\mathrm{CO}_{2}$ as carbonates are decomposed into oxides through the application of heat. The heat is generated by the combustion of fossil fuels, which adds to the carbon intensity. The total $\mathrm{CO}_{2}$ emissions from cement manufacturing are estimated at $8 \%$ of the world total [87]. For the basic metals sector, our results are somewhat consistent with those of [88], who found that Portugal and Lithuania are among the most competitive countries in this industry from the perspective of energy, emissions, and export performance indicators, whereas Czechia and Ireland are among the least competitive. In our case, Portugal and Lithuania registered a high performance with a low ratio (5\% and 1\%, respectively), whereas Czechia and Ireland have a high ratio (50\% and $38 \%$, respectively). In addition to taking into account other indicators as a measure of performance, the analysis of the previous study is restricted to EU Member States that are also members of the International Energy Agency, and therefore excludes some Eastern European countries. This makes a direct comparison with our results difficult.

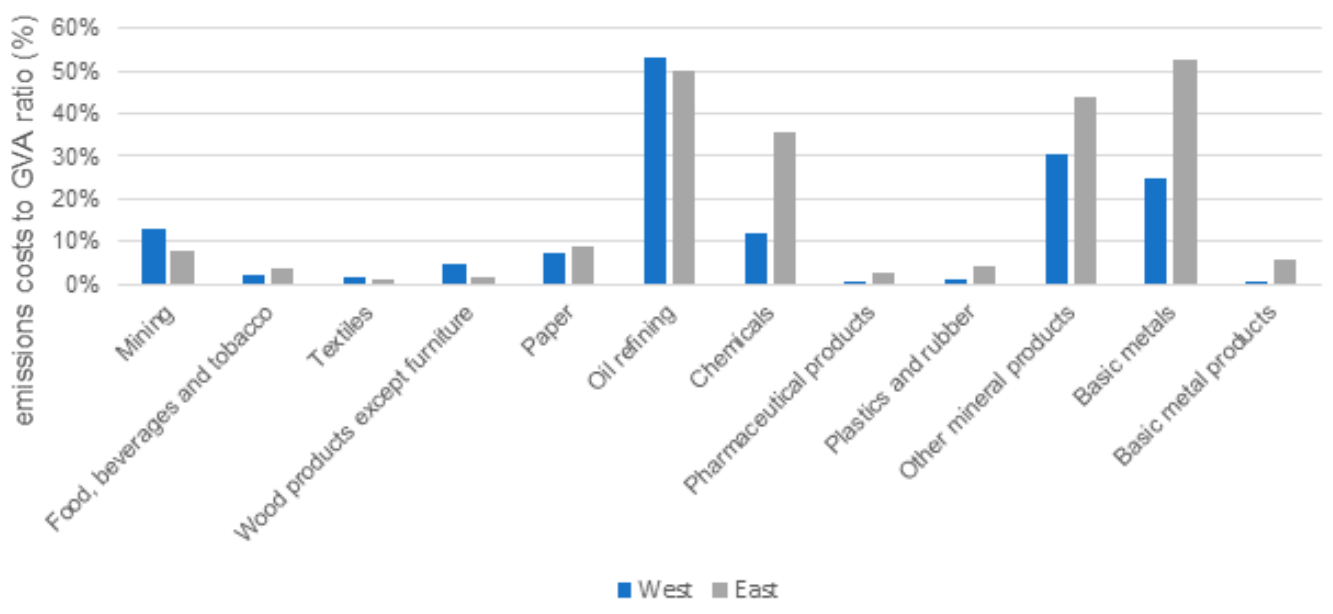

Figure 10. Potential emissions costs to GVA for main industrial sectors-weighted average. Note: Mining includes quarrying and oil and gas extraction.

\section{Conclusions}

In the present study, we provided an assessment of the carbon price risk across all economic sectors of all EU Member States. The novelty of the research was the application of risk management methodologies used by companies and financial institutions at the macroeconomic level in order to gain a holistic view of the risk exposure. Specifically, we estimated the $90 \% \mathrm{VaR}$ for the carbon price log returns under the ETS over a 91-day period via two methods. The first method was a historical simulation based on returns recorded for the fourth phase of the ETS, meaning that we restricted the dataset to the January 
2021-August 2021 period. For the second method, we estimated an AR(2)-GARCH(1,1) model using the entire dataset available (October 2012-August 2021). The 91-day window was motivated by the remaining working days in 2021, which allows for estimating a price for the end of the year. The price obtained for the historical simulation method was higher due to the use of data covering a period of high price growth. We also estimated the 250-day VaR log returns and applied these to the price at the beginning of 2021 to yield a price estimate for the end of the year. Interestingly, the values obtained in both cases were comparable due to the high carbon price increases recorded from the start of 2021, making the VaR methodology particularly suitable for periods marked by expectations of significant price increases.

Our second contribution was the application of the historical simulation price to the GHG emissions of each economic sector in the EU in order to gain an estimate of the potential costs. We further proceeded to divide this by the respective sector's GVA to obtain what may be referred to as a value erosion metric. Although the differences among sectors and countries were strictly due to the GHG emissions and GVA, our approach allows for the identification of financial risk exposure by introducing the price estimate. This goes beyond a simple GHG intensity ratio by highlighting the sectors that are at risk of losing a high portion of their profitability. Moreover, we examined differences between Eastern and Western EU countries, which led to some interesting findings. First, the ratio for the energy supply sector in Eastern nations is consistently high, meaning that there is high potential for large losses. Western nations are faced with the same problem, but to a lesser extent. Performance is explained largely by the energy mix, with countries least dependent on fossil fuels registering lower ratios. Second, although the refining sector appears to be highly vulnerable, there are no significant differences between the Eastern and Western groups of countries in this regard. This is possibly due to the considerable restructuring which has affected this industry across all of Europe. The chemicals sector performs better on average, but a large divide can be observed between the East and West, with the former showing worse results. This may be caused by a slower restructuring of this sector in Eastern Europe or a focus on lower value-added products. Such large divides are also registered for the other mineral products and basic metals industries.

The analysis may be of great use for policymakers by allowing for a better assessment of the energy transition risk across economic sectors within the EU. This is especially important during times of high volatility. The divide between East and West, significant in some sectors but absent or relatively small in others, is especially noteworthy and may serve to better guide policy. Nevertheless, we must point out some limitations. First, the methodology is best suited for estimating near-term risk over a period of around one year. Extending this to longer periods may yield unrealistic results such as prices in the thousands of EUR per tonne. This may also be the case if the VaR level is set too high. Second, the VaR can be estimated through other methods (for example exponential smoothing) and the expected shortfall can also be computed-this is the average of the losses above the VaR confidence level. This was beyond the scope of the present study because our objective was to prove the viability of this methodology. Third, we restricted GHG emissions to the three gases currently covered by the ETS. This was motivated by the near-term character of the analysis; however, because the goal is to eradicate all GHGs, including all them may offer better insights into the resilience of industries, or lack thereof. Finally, we offered no comprehensive explanation of the differences in performance across countries because this depends on a large number of factors, such as the regulatory and economic environment of each country, in addition to the particularities of each industrial installation. Moreover, many industrial assets are owned by multinational corporations, which means that their performance is affected by the policies and decisions of the parent company. Investigating this further may be a fruitful avenue for future research. 
Author Contributions: Conceptualization, V.-C.B., A.H., O.C.P. and L.B.; methodology, V.-C.B.; investigation, A.H., V.-C.B., O.C.P., L.B. and S.A.D.; writing-A.H., V.-C.B. and O.C.P., writingreview and editing, A.H., V.-C.B., O.C.P., L.B. and S.A.D.; supervision: A.H. All authors have read and agreed to the published version of the manuscript.

Funding: This research received no external funding.

Institutional Review Board Statement: Not applicable.

Informed Consent Statement: Not applicable.

Data Availability Statement: Data used in this study is sourced from official public sources (Eurostat) and Thomson Reuters and is available from these sources to all.

Conflicts of Interest: The authors declare no conflict of interest.

\section{Appendix A}

Table A1. AR Model selection.

\begin{tabular}{cc}
\hline Model & Bayesian Information Criterion (BIC) \\
\hline AR1 & -8843.79 \\
\hline AR2 & -8850.20 \\
\hline AR3 & -8844.63 \\
\hline ARMA11 & -8838.72 \\
\hline ARMA21 & -8843.40 \\
\hline ARMA31 & -8840.14 \\
\hline ARMA12 & -8841.75 \\
\hline ARMA13 & -8835.63 \\
\hline
\end{tabular}

Source: Authors' calculations.

\section{References}

1. IPCC. Climate Change 2021: The Physical Science Basis. In Contribution of Working Group I to the Sixth Assessment Report of the Intergovernmental Panel on Climate Change; Masson-Delmotte, V.P., Zhai, A., Pirani, S.L., Connors, C., Péan, S., Berger, N., Caud, Y., Chen, L., Goldfarb, M.I., Gomis, M., et al., Eds.; Cambridge University Press: Cambridge, UK, 2021; in press.

2. Tamma, P.; Schaart, E.; Gurzu, A. Europe's Green Deal Plan Unveiled. Available online: https://www.politico.eu/article/thecommissions-green-deal-plan-unveiled/ (accessed on 2 October 2020).

3. Simon, F. EU Commission Unveils 'European Green Deal': The Key Points. Available online: EURACTIV.com (accessed on 2 October 2021).

4. Bayer, P.; Aklin, M. The European Union emissions trading system reduced $\mathrm{CO}_{2}$ emissions despite low prices. Proc. Natl. Acad. Sci. USA 2020, 117, 8804-8812. [CrossRef]

5. Guo, J.; Gu, F.; Liu, Y.; Liang, X.; Mo, J.; Fan, Y. Assessing the impact of ETS trading profit on emission abatements based on firm-level transactions. Nat. Commun. 2020, 11, 2078. [CrossRef]

6. European Commission. Directive 2003/87/EC of the European Parliament and of the Council of 13 October 2003 Establishing a Scheme for Greenhouse Gas Emission Allowance Trading within the Community, Official Journal of the European Union L 275/32. Available online: https:/ / eur-lex.europa.eu/legal-content/EN/TXT/?uri=CELEX:32003L0087 (accessed on 2 October 2021).

7. European Commission. Proposal for a Directive of the European Parliament and of the Council Amending Directive 2003/87/EC Establishing a System for Greenhouse Gas Emission Allowance Trading within the Union, Decision (EU) 2015/1814 Concerning the Establishment and Operation of a Market Stability Reserve for the Union Greenhouse Gas Emission Trading Scheme and Regulation (EU) 2015/757. 2021. Available online: https:/ / ec.europa.eu/info/sites / default/files/revision-eu-ets_with-annex_ en_0.pdf (accessed on 2 October 2021).

8. Verbruggen, A.; Laes, E.; Woerdman, E. Anatomy of emissions trading systems: What is the EU ETS? Environ. Sci. Policy 2019, 8 , 11-19. [CrossRef]

9. Fischer, C.; Newell, R.G. Environmental and technology policies for climate mitigation. J. Environ. Econ. Manag. 2008, 55, 142-162. [CrossRef]

10. Zhang, Y.J. Research on carbon emission trading mechanisms: Current status and future possibilities. Int. J. Glob. Energy Issues 2016, 39, 89-107. [CrossRef] 
11. Doege, J.; Fehr, M.; Hinz, J.; Lüthi, H.J.; Wilhelm, M. Risk management in power markets: The hedging value of production flexibility. Eur. J. Oper. Res. 2009, 199, 936-943. [CrossRef]

12. Fan, J.H.; Roca, E.; Akimov, A. Estimation and performance evaluation of optimal hedge ratios in the carbon market of the European Union Emissions Trading Scheme. Aust. J. Manag. 2014, 39, 73-91. [CrossRef]

13. Zhang, F.; Zhang, Z. The tail dependence of the carbon markets: The implication of portfolio management. PLoS ONE 2020 15, e0238033. [CrossRef]

14. Edmonds, J.; Yu, S.; Mcjeon, H.; Forrister, D.; Aldy, J.; Hultman, N.; Cui, R.; Waldhoff, S.; Clarke, L.; Clara, S.D.; et al. How Much Could Article 6 Enhance Nationally Determined Contribution Ambition Toward Paris Agreement Goals Through Economic Efficiency? Clim. Chang. Econ. 2021, 12, 2150007. [CrossRef]

15. Li, Y.; Wei, Y. Estimating the potential $\mathrm{CO}_{2}$ emission reduction in 97 contracting countries of the Paris Agreement. Clim. Chang. Econ. 2021, 12, 1-36. [CrossRef]

16. Parry, I.; Mylonas, V.; Vernon, N. Mitigation Policies for the Paris Agreement: An Assessment for G20 Countries. J. Assoc. Environ. Resour. Econ. 2021, 8, 797-823. [CrossRef]

17. European Commission. Directive 2018/410 of the European Parliament and of the Council of 14 March 2018 Amending Directive 2003/87/EC to Enhance Cost-Effective Emission Reductions and Low-Carbon Investments, and Decision (EU) 2015/1814, Official Journal of the European Union L 76/3. 2018. Available online: https:/ / eur-lex.europa.eu/legal-content/EN/TXT/PDF/?uri= CELEX:32018L0410\&from $=E N$ (accessed on 2 October 2021).

18. Newbery, D.M.; Reiner, D.M.; Ritz, R.A. The Political Economy of a Carbon Price Floor for Power Generation. Energy J. 2019, 40, 1-26. [CrossRef]

19. Koch, N.; Fuss, S.; Grosjean, G.; Edenhofer, O. Causes of the EU ETS price drop: Recession, CDM, renewable policies or a bit of everything?-New evidence. Energy Policy 2014, 73, 676-685. [CrossRef]

20. Flachsland, C.; Pahle, M.; Burtraw, D.; Edenhofer, O.; Elkerbout, M.; Fischer, C.; Tietjen, O.; Zetterberg, L. How to avoid history repeating itself: The case for an EU Emissions Trading System (EU ETS) price floor revisited. Clim. Policy 2020, 20, 133-142. [CrossRef]

21. Aldy, J.E.; Stavins, R.N. The promise and problems of pricing carbon: Theory and experience. J. Environ. Dev. 2012, 21, 152-180. [CrossRef]

22. Ranson, M.; Stavins, R.N. Linkage of greenhouse gas emissions trading systems: Learning from experience. Clim. Policy 2016, 16, 284-300. [CrossRef]

23. Dutta, A.; Jalkh, N.; Bouri, E.; Dutta, P. Assessing the risk of the European Union carbon allowance market: Structural breaks and forecasting performance. Int. J. Manag. Financ. 2019, 16, 49-60. [CrossRef]

24. Viteva, S.; Veld-Merkoulova, Y.V.; Campbell, K. The forecasting accuracy of implied volatility from ECX carbon options. Energy Econ. 2014, 45, 475-484. [CrossRef]

25. Zhang, Y.J.; Sun, Y.F. The dynamic volatility spillover between European carbon trading market and fossil energy market. J. Clean. Prod. 2016, 112, 2654-2663. [CrossRef]

26. Balcılar, M.; Demirer, R.; Hammoudeh, S.; Nguyen, D.K. Risk spillovers across the energy and carbon markets and hedging strategies for carbon risk. Energy Econ. 2016, 54, 159-172. [CrossRef]

27. Skjærseth, J.B.; Wettestad, J. Implementing EU emissions trading: Success or failure? Int. Environ. Agreem. 2008, 8, 275-290. [CrossRef]

28. Zaklan, A.; Wachsmuth, J.; Duscha, V. The EU ETS to 2030 and beyond: Adjusting the cap in light of the $1.5^{\circ} \mathrm{C}$ target and current energy policies. Clim. Policy 2021, 21, 778-791. [CrossRef]

29. Springer, U. The market for tradable GHG permits under the Kyoto Protocol: A survey of model studies. Energy Econ. 2003, 25, 527-551. [CrossRef]

30. Benz, E.; Trück, S. Modeling the price dynamics of $\mathrm{CO}_{2}$ emission allowances. Energy Econ. 2009, 31, 4-15. [CrossRef]

31. Conrad, C.; Rittler, D.; Rotfuß, W. Modeling and explaining the dynamics of European Union Allowance prices at high-frequency. Energy Econ. 2012, 34, 316-326. [CrossRef]

32. Nazifi, F. Modelling the price spread between EUA and CER carbon prices. Energy Policy 2013, 56, 434-445. [CrossRef]

33. Zhu, B.; Ma, S.; Chevallier, J.; Wei, Y. Modelling the dynamics of European carbon futures price: A Zipf analysis. Econ. Model. 2014, 38, 372-380. [CrossRef]

34. Carnero, M.; Olmo, J.; Pascual, L. Modelling the Dynamics of Fuel and EU Allowance Prices during Phase 3 of the EU ETS. Energies 2018, 11, 3148. [CrossRef]

35. Hao, Y.; Tian, C.; Wu, C. Modelling of carbon price in two real carbon trading markets. J. Clean. Prod. 2020, 244, 118556. [CrossRef]

36. Fang, S.; Cao, G. Modelling extreme risks for carbon emission allowances-Evidence from European and Chinese carbon markets. J. Clean. Prod. 2021, 316, 128023. [CrossRef]

37. Arouri, M.E.; Jawadi, F.; Nguyen, D.K. Nonlinearities in carbon spot-futures price relationships during Phase II of the EU ETS. Econ. Model. 2012, 29, 884-892. [CrossRef]

38. Gil-Alana, L.A.; Gupta, R.; de Gracia, F.P. Modeling persistence of carbon emission allowance prices. Renew. Sustain. Energy Rev. 2016, 55, 221-226. [CrossRef]

39. Gil-Alana, L.A.; Cunado, J.; Gupta, R. Persistence, Mean-Reversion and Non-linearities in $\mathrm{CO}_{2}$ Emissions: Evidence from the BRICS and G7 Countries. Environ. Resour. Econ. 2017, 67, 69-83. [CrossRef] 
40. Churchill, S.A.; Inekwe, J.; Smyth, R.; Zhang, X. R\&D intensity and carbon emissions in the G7: 1870-2014. Energy Econ. 2019, 80, 30-37.

41. Gianfreda, A.; Grossi, L. Quantitative analysis of energy markets. Energy Econ. 2013, 35, 1-4. [CrossRef]

42. Alberola, E.; Chevallier, J.; Chèze, B. Price drivers and structural breaks in European carbon prices 2005-2007. Energy Policy 2008, 36, 787-797. [CrossRef]

43. Chevallier, J. Carbon futures and macroeconomic risk factors: A view from the EU ETS. Energy Econ. 2009, 31, 614-625. [CrossRef]

44. Mansanet-Bataller, M.; Pardo, A.; Valor, E. $\mathrm{CO}_{2}$ prices, energy and weather. Energy J. 2007, 28, 73-92. [CrossRef]

45. Christiansen, A.C.; Arvanitakis, A.; Tangen, K.; Hasselknippe, H. Price determinants in the EU emissions trading scheme. Clim. Policy 2005, 5, 15-30. [CrossRef]

46. Ellerman, A.D.; Buchner, B.K. Over-allocation or abatement? A preliminary analysis of the EU ETS based on the 2005-06 emissions data. Environ. Resour. Econ. 2008, 41, 267-287. [CrossRef]

47. Bredin, D.; Muckley, C. An emerging equilibrium in the EU emissions trading scheme. Energy Econ. 2011, 33, 353-362. [CrossRef]

48. Aatola, P.; Ollikainen, M.; Toppinen, A. Price determination in the EU ETS market: Theory and econometric analysis with market fundamentals. Energy Econ. 2013, 36, 380-395. [CrossRef]

49. Yu, J.; Mallory, M.L. Exchange rate effect on carbon credit price via energy markets. J. Int. Money Financ. 2014, 47, 145-161. [CrossRef]

50. Chevallier, J. Evaluating the carbon-macroeconomy relationship: Evidence from threshold vector error-correction and Markovswitching VAR models. Econ. Model. 2011, 28, 2634-2656. [CrossRef]

51. Hammoudeh, S.; Nguyen, D.K.; Sousa, R.M. What explain the short-term dynamics of the prices of $\mathrm{CO}_{2}$ emissions? Energy Econ. 2015, 46, 122-135. [CrossRef]

52. Bunn, D.W.; Fezzi, C. A vector error correction model of the interactions among gas, electricity and carbon prices: An application to the cases of Germany and the United Kingdom. In Markets for Carbon and Power Pricing in Europe: Theoretical Issues and Empirical Analyses; Edward Elgar Publishing Limited: Cheltenham, UK, 2008; pp. 145-159.

53. Kanamura, T. Role of carbon swap trading and energy prices in price correlations and volatilities between carbon markets. Energy Econ. 2016, 54, 204-212. [CrossRef]

54. Chen, Y.; Qu, F.; Li, W.; Chen, M. Volatility spillover and dynamic correlation between the carbon market and energy markets. J. Bus. Econ. Manag. 2019, 20,979-999. [CrossRef]

55. Markusson, N.; Kern, F.; Watson, J.; Arapostathis, S.; Chalmers, H.; Ghaleigh, N.; Heptonstall, P.; Pearson, P.; Rossati, D.; Russell, S. A socio-technical framework for assessing the viability of carbon capture and storage technology. Technol. Forecast. Soc. Chang. 2012, 79, 903-918. [CrossRef]

56. Sheil, D.; Ladd, B.; Silva, L.C.; Laffan, S.W.; Van Heist, M. How are soil carbon and tropical biodiversity related? Environ. Conserv. 2016, 43, 231-241. [CrossRef]

57. Carton, W. Dancing to the rhythms of the fossil fuel landscape: Landscape inertia and the temporal limits to market-based climate policy. Antipode 2017, 49, 43-61. [CrossRef]

58. Hua, W.; Li, D.; Sun, H.; Matthews, P. Stackelberg game-theoretic model for low carbon energy market scheduling. IET Smart Grid 2020, 3, 31-41. [CrossRef]

59. La Notte, A.; Tonin, S.; Lucaroni, G. Assessing direct and indirect emissions of greenhouse gases in road transportation, taking into account the role of uncertainty in the emissions inventory. Environ. Impact Assess. Rev. 2018, 69, 82-93. [CrossRef]

60. Dey, S.; Caulfield, B.; Ghosh, B. Modelling uncertainty of vehicular emissions inventory: A case study of Ireland. J. Clean. Prod. 2019, 213, 1115-1126. [CrossRef]

61. Gonçalves, D.N.; Goes, G.V.; Márcio de Almeida, D.A.; de Mello Bandeira, R.A. Energy use and emissions scenarios for transport to gauge progress toward national commitments. Energy Policy 2019, 135, 110997. [CrossRef]

62. Güzel, T.D.; Alp, K. Modeling of greenhouse gas emissions from the transportation sector in Istanbul by 2050. Atmos. Pollut. Res. 2020, 11, 2190-2201. [CrossRef]

63. Busch, T.; Hoffmann, V.H. Emerging carbon constraints for corporate risk management. Ecol. Econ. 2007, 62, 518-528. [CrossRef]

64. Koch, N.; Bassen, A. Valuing the carbon exposure of European utilities. The role of fuel mix, permit allocation and replacement investments. Energy Econ. 2013, 36, 431-443. [CrossRef]

65. Busch, T.; Weinhofer, G.; Hoffmann, V.H. The carbon performance of the 100 largest US electricity producers. Util. Policy 2011, 19, 95-103. [CrossRef]

66. Tulloch, D.J.; Diaz-Rainey, I.; Premachandra, I.M. The impact of liberalization and environmental policy on the financial returns of European energy utilities. Energy J. 2017, 38, 77-106. [CrossRef]

67. Bernardini, E.; Di Giampaolo, J.; Faiella, I.; Poli, R. The impact of carbon risk on stock returns: Evidence from the European electric utilities. J. Sustain. Financ. Invest. 2021, 11, 1-26. [CrossRef]

68. Oestreich, A.M.; Tsiakas, I. Carbon emissions and stock returns: Evidence from the EU Emissions. J. Bank. Financ. 2015, 58, 294-308. [CrossRef]

69. Moreno, B.; da Silva, P.P. How do Spanish polluting sectors' stock market returns react to European Union allowances prices? A panel data approach. Energy 2016, 103, 240-250. [CrossRef]

70. Witkowski, P.; Adamczyk, A.; Franek, S. Does Carbon Risk Matter? Evidence of Carbon Premium in EU Energy-Intensive Companies. Energies 2021, 14, 1855. [CrossRef] 
71. Choi, D.; Gao, Z.; Jiang, W. Measuring the Carbon Exposure of Institutional Investors. J. Altern. Invest. 2020, 23, 12-23. [CrossRef]

72. Hunt, C.; Weber, O. Fossil fuel divestment strategies: Financial and carbon-related consequences. Organ. Environ. 2019, 32, 41-61. [CrossRef]

73. Benz, L.; Paulus, S.; Scherer, J.; Syryca, J.; Trück, S. Investors' carbon risk exposure and their potential for shareholder engagement. Bus. Strategy Environ. 2021, 30, 282-301. [CrossRef]

74. Trucost. Carbon Risks in UK Equity Funds. Available online: http://assets.wwf.org.uk/downloads/carbonrisksinukequityfunds. pdf (accessed on 2 October 2021).

75. Blyth, W.; Bradley, R.; Bunn, D.; Clarke, C.; Wilson, T.; Yang, M. Investment risks under uncertain climate change policy. Energy Policy 2007, 35, 5766-5773. [CrossRef]

76. Yang, M.; Blyth, W.; Bradley, R.; Bunn, D.; Clarke, C.; Wilson, T. Evaluating the power investment options with uncertainty in climate policy. Energy Econ. 2008, 30, 1933-1950. [CrossRef]

77. Aldy, J.E.; Pizer, W.A. The competitiveness impacts of climate change mitigation policies. J. Assoc. Environ. Resour. Econ. 2015, 2, 565-595. [CrossRef]

78. Cyrek, M.; Cyrek, P. Does Economic Structure Differentiate the Achievements towards Energy SDG in the EU? Energies 2021, 14, 2229. [CrossRef]

79. Stambaugh, F. Risk and value at risk. Eur. Manag. J. 1996, 14, 612-621. [CrossRef]

80. Neath, A.A.; Cavanaugh, J.E. The Bayesian information criterion: Background, derivation, and applications. Wiley Interdiscip. Rev. Comput. 2012, 4, 199-203. [CrossRef]

81. Engle, R.F. Autoregressive conditional heteroscedasticity with estimates of the variance of United Kingdom inflation. Econometrica 1982, 50, 987-1007. [CrossRef]

82. Bollerslev, T. Generalized autoregressive conditional heteroskedasticity. J. Econom. 1986, 31, 307-327. [CrossRef]

83. Wilhelmsson, A. GARCH forecasting performance under different distribution assumptions. J. Forecast. 2006, 25, 561-578. [CrossRef]

84. Nelson, D.B. Conditional heteroskedasticity in asset returns: A new approach. Econometrica 1991, 59, 347-370. [CrossRef]

85. Glosten, L.R.; Jagannathan, R.; Runkle, D.E. On the relation between the expected value and the volatility of the nominal excess return on stocks. J. Financ. 1993, 48, 1779-1801. [CrossRef]

86. Ginevičius, R.; Bilan, Y.; Kądzielawski, G.; Novotny, M.; Kośmider, T. Evaluation of the Sectoral Energy Development Intensity in the Euro Area Countries. Energies 2021, 14, 5298. [CrossRef]

87. Andrew, R.M. Global $\mathrm{CO}_{2}$ emissions from cement production. Earth Syst. Sci. Data 2018, 10, 195-217. [CrossRef]

88. Zuoza, A.; Pilinkienè, V. Energy efficiency and carbon emission impact on competitiveness in the European energy intensive industries. Energies 2021, 14, 4700. [CrossRef] 